\title{
HISTORY OF EDUCATION - SOLID OR UNNECESSARY PART OF PEDAGOGICAL KNOWLEDGE ${ }^{1}$
}

\author{
Roman Tomaszewski
}

\section{Resume}

The process of modernization in the $19^{\text {th }}$ century enabled pedagogy to establish its identity but the fascination of the empirical knowledge of the $20^{\text {th }}$ century was to provide it with an efficiency of technical sciences. History of education as a kind of a cumulated pedagogical experience became an ornament of empirical researches. It does not allow verification of the set of educational reforms between the $19^{\text {th }}$ and $20^{\text {th }}$ centuries or organize the pedagogical researches contemporarily treated as historical creations. As a result of this history of education was reduced in the Polish pedagogical higher education.

\section{Key words}

Time, education, change, pedagogy without history, the world without history.

\section{Historie vzdělávání - pevná a nezbytná součást pedagogického poznání}

\section{Resumé}

Díky komplexnímu procesu modernizace byl v 19. století stabilizován obor pedagogika. Současně ovšem fascinace možnostmi empirického poznání způsobila, že byly v tomto období výrazně posíleny technické vědy. Historie pedagogiky se stala pouhým př́idavkem či ozdobou empirických pedagogických výzkumů. $\mathrm{Z}$ tohoto důvodu nebyl zpracován důsledný výzkum, který by utřídil poznatky o systému vzdělávacích reforem $\mathrm{v} 19$. a 20. století a který by zhodnotil jejich historický význam. Důsledkem je fakt, že v polském vysokoškolském pedagogickém vzdělávání došlo k redukci tématu historie vzdělávání.

\footnotetext{
${ }^{1}$ The text is an attempt to present a discussion about historicism in Polish academic pedagogy. It is written from the Polish point of view and refers to main issues: Polish educational reforms in the $20^{\text {th }}$ century and pedagogical standards.
} 


\section{Klíčová slova}

Čas, vzdělávání, změna, pedagogika bez historie, svět bez historie.

\section{Introduction}

The great ideas of Enlightenment were absorbed by social minds through the educational reforms initiated in the second part of $18^{\text {th }}$ century. The French Revolution only speeded up the whole process, however for the educational reforms to be real and fulfilled there was a need of technology to make it possible. There was a demand for another scientific and technological revolution. The ideas and the earlier educational reforms of the $18^{\text {th }}$ century and the first six or seven decades of the $19^{\text {th }}$ century had a little impact due to the limitations in technology or social conservatism. Its creators or protectors - even the monarchs cannot be accused of having bad intentions but they committed many mistakes.

The effect of modernization was first noticed in the seventh decade of the $19^{\text {th }}$ century when there was an increased movement in economical relationships and in industrialization and urbanization. The high number of population and the rapid development in communication led to the fact that schools were in a near distance. The duty of education which already had existed in most of the European countries was then enhanced. From this moment in time the educational aspirations of middle and higher social class were accompanied by the need of the elementary mass education which was not a case of philanthropy or charity. The new man in a modern society should not have been illiterate. For these the seventh and the following decades of the $19^{\text {th }}$ century were known for their educational reforms: Albert Falk's in Germany, Józef Dietl in Galicia, Aleksander Wielopolski's in Polish Kingdom. Alongside with the above stated the Hasner's reform on Czech's lands has to be mentioned.

As well as the Czech's lands, Galicia belonged to Austria so the possibility of passing any reforms by Hasner or Dielt were a result of a forced autonomy. The changes that took place after 1866 in Czech speaking and Polish speaking areas of the monarchy within the school field and a long term meaning. They settled the organizational school systems in the thirstiest of the $19^{\text {th }}$ century because the Polish one from 1919 and the Czechoslovakian one from 1922 were based on Dielt's or Hasner's standards.

In case of Central Europe the important factor of the modernization process turned out to be the institution of a modern university from Berlin (1809). During the times of breakthrough in the political and social opposition the aca- 
demic intellectualists became a modern model. They were initializing the liberal ideas. ${ }^{2}$ Within the university buildings there was an initialization of pedagogy taking place and its structure was being established and divided into disciplines: general pedagogy (philosophy of education), didactics, and the history of education. ${ }^{3}$ The process of creating pedagogical departments was long and lasted between 1779 and 1871. It was connected to additional educational functions of the teachers and due to the amount of the didactic staff the reforms of Hasner, Dietl and Falk were limited. After 1980 the pedagogical departments in Austria were treated with a distance or reduced. Pedagogy was becoming a younger sister of philosophy, history and theology and through them pedagogy was acquiring the styles and knowledge as well as teaching methods but also through them it was gaining its staff. Using the words of Wolfagng Brzezinki, "they were sober and did not tolerate the pedagogical prattle." It was them who with their educational authority taken from the (older) disciplines supported the scientific function of pedagogy in the $19^{\text {th }}$ century.

Both mentioned elements: the modern effect and the emancipation of pedagogy proved the success of educational reforms, starting between the sixties and seventies of the $19^{\text {th }}$ century.

The following changes in school systems in Central Europe which took place in the $20^{\text {th }}$ century had a slightly different character in the interwar times than over the traumatic times of the Second World War. However they cannot analyzed as two separate items. According to the prof. Julian Dybiec from the Jagieloński University "History of Education as a knowledge is a deposit of cumulated pedagogical experience, a verifier of successful and unsuccessful educational reforms, innovations and changes." ${ }^{5}$ The following reforms of Polish education from 1932-1934 when the so called Jędrzejowska Reform was unifying the three different school systems in annexations; from 1948 when the communist government was trying to interfere in educational system of after-war Poland and took over the control over schooling, and from 1961 when the main intention of the government was secularization. There was also the unsuccessful

${ }^{2}$ T. Nipperdey, Rozważania o niemieckiej historii, Warszawa 1999, p. 343.

${ }^{3}$ T. Hejnicka- Bezwińska, Pedagogika Ogólna, Warszawa 2008, pp. 107-112.

${ }^{4}$ W. Brezinka, Wychowanie i pedagogika w dobie przemian kulturowych, Kraków 2008, pp. 139-140.

${ }^{5}$ J. Dybiec, Historia wychowania, historyk wychowania i standardy. Treści historyczne w studiach pedagogicznych, red. K. Bartnicka, Pułtusk 2007, pp. 139-140. 
reform of Jerzy Kuberski in 1973 and the post communist reform in 1999 by prof. Handke which should not be discussed separately. ${ }^{6}$

I personally believe that changes in the Czech educational system should have a chapter in the Czech history of education. It should include Hasner's reforms up to the establishing of the Czech Republic and applying European Union standards. We should all try to link the strategies of "long lastingness" with a respect to certain facts. ${ }^{7}$

Historical orientation in pedagogical reflection was an everyday element of the $19^{\text {th }}$ century because history had become an approved branch of knowledge earlier than pedagogy. Its usefulness was noticed by Herbart. ${ }^{8}$ History is a valid source of knowledge when analyzing the reforms. However it does not excuse the attempt to separate history of education from history of pedagogy as the second one is a part of the first one. ${ }^{9}$ History of education cannot be only a supportive area in pedagogy which could only deal with a "pre-pedagogical" times. It is made to study times up to contemporary days. The meeting point of the distant history with the close history is commonly described as "the final word" which is known to the historians of the education. But only reaching "the final word" may explore the future..$^{10}$ Into the future where "the final word" has to be discovered and 140 years since the Hasner's, Dielt's and Falk's reforms have to draw the future. The analysis of any changes within educational - political area have to be reached through history of education. There is no idea that comes from nowhere.

The above mentioned idea may lead to the unification of humanistic sciences, no matter whether such changes would take place around the history or pedagogy. History of education may become canvas for other disciplines to put colours shades on it. Each discipline has its unique colour. ${ }^{11}$

\footnotetext{
${ }^{6}$ The First Czechoslovakian Republic did not have a problem of unification of the educational system between 1918 and 1939 because the Czech and the Slovak lands were in one country.

${ }^{7}$ F. Braudel, Gramatyka cywilizacji, Warszawa 2006, p. 23.

${ }^{8}$ T. Hejnicka-Bezwińska, op. cit., p. 31.

${ }^{9}$ Ibidem, p. 243.

${ }^{10}$ F. Braudel, op. cit., p. 31.

11 "It is possible to stay in a certain historical period of time in case of a detailed study. But when it comes to the synthesis - when talking about history of civilization - we need to gather the maximum amount of the paintings created in different times, which then should be combined into one according to the sunlight pattern which mixed together give one bright light.”, F. Braudel, op. cit., p. 33.
} 
Since Herbart's ideas, history of education was playing an important role in educational, mathematical and technical disciplines. However at the beginning of the $20^{\text {th }}$ century pedagogy faced criticism. Prof. T. Szkudlarek seems to present the pedagogical view best in 1993: "it is difficult to find people from outside of its (pedagogy - R. T.) professional areas, who would take it seriously." 12 This notion was presented in November 1993, so a few months after the $1^{\text {st }}$ Pedagogical Congregation in Poland after the political system had changed. Was the postmodernist reaction leading to hesitations in its scientific value? I personally doubt it. Similarly to limitations in the history of education, other sub-disciplines such as the history of pedagogical ideas or history of pedagogy cannot guarantee similar nobility. The pedagogical knowledge created this way leads to narrowing or limiting the historical knowledge and makes the history of education a "grey area." Obviously postmodern history is impossible, although there was an attempt to establish a postmodern pedagogy..$^{13}$ There is a discussion over the question if the first part of the $20^{\text {th }}$ century can be described as "late modernity", which proves winning over the past and usefulness of the past. Using the historical perspective in the latest Polish book of general pedagogy allows us to hope that historicism will be returned to the educational disciplines in Poland. ${ }^{14}$

History of education had an unquestioned position in Polish pedagogy in 1948. It was present in pedagogical researches and during the historical congregations in 1925 and 1948, where special sections of history of education. Due to the political systems it was absorbed by the communism in 1949. Also the "cultural delay" during the 50s-70s did not have a positive influence on history of education. It is worth mentioning on the areas of the strong Soviet influence the development was limited. History of education in pedagogy was only to prove the ethos of a "great educator - institutional communism." It led to a low profile of history of education didactics which refused to analysis of history after 1944. As a result of which other representatives of university pedagogy started to treat history of education as a necessary evil. The changes in political system in 1989/1990 brought hope.

\footnotetext{
${ }^{12}$ T. Szudlarek, Pedagogizm i pedagogika, Racjonalność pedagogiki, red. Hejnicka-Bezwińska, Bydgoszcz 1995, p. 41.

${ }^{13}$ B. Szacka, Czas przeszły pamięć mit, Warszawa 2006, pp. 24-25.B. Szacka brings examples of representatives of young American historians society: J. Appelby, L. Hunt, M. Jacob are not consequent in their believes and present their feminism. (Powiedzieć prawdę o historii, Poznań 2000.)

${ }^{14}$ T. Hejnicka-Bezwińska, Pedagogika ogólna, Warszawa 2008.
} 
During the $1^{\text {st }}$ Pedagogical Congregation (Warszawa-Rembertów 1993) the studies of the $7^{\text {th }}$ section were dedicated to the negligence of history of education, which were described as "blank spots". Educationalists who then were dealing with history of education managed to establish the key objectives for their sub-discipline and to describe their preferences within the contemporary studies. Fascinating was the openness on the western history - free modernism. It was then when the dilemma included in this topic came out - is history of education a solid or unnecessary part of educational knowledge?

Historians of education were accused of antiquarian ideas in their researches and taking up the so called "history of events".

The American pragmatism was supporting the freedom from the past. Historicism as a symbol of change was not in favor. Pedagogy treated earlier as a integrated branch of knowledge became an untidy group of unclear theories. The visions of Fukuyama, Toffler and others were against the idea of evolution changes and they claimed that history is valueless discipline. ${ }^{15}$ during the last decades of the $2^{\text {th }}$ century the ideas were accepted without any criticism. Nobody paid attention to the Karl Popper's approach who in "Nędza historycyzmu” (The Poverty of Historicismus) (London - New York 1992) admitted that „I was trying to prove historicism is a dead method. The method which does not bring any friut. But in fact, I did not demolish it." 16

The attempt to win over the differences between the supporters of historicism and antihistoricism in Polish pedagogy took place during the $5^{\text {th }}$ Pedagogical Congregation in Wrocław, in 2004. It only led to highlighting the differences. It became even more visible in Polish academic pedagogy books. In the book from 2003, a chapter dedicated to the history of education was written by prof. Wołoszyn who represents the pre-war pedagogical and humanistic approach. ${ }^{17}$ However, in 2006 it was accomplished by the representative of the trend which was supporting the reduction of historicism in pedagogy, and at the same time the representative of the younger generation of educationalists - S. Sztobryn..$^{18}$ The characteristic feature for both narrations is treating

\footnotetext{
${ }^{15}$ W. Brezinka, Wychowanie i pedagogika..., op. cit., pp. 170-173; T. Hejnicka-Bezwińska, op. cit., p. 204; F. Fukuyama, Koniec historii, Poznań 1996; A. Toffler, Szok przyszłości, Poznań 1998, pp. 381-395.

${ }^{16}$ K.R. Popper, Nędza historycyzmu, Warszawa 1999, p. 9.

${ }^{17}$ S. Wołoszyn, Rozwój i zmienność wychowania i ksztatcenia, Pedagogika. Podręcznik akademicki. red. Z. Kwiecińska and B. Śliwerski, t. 1, Warszawa 2003, pp. 74-182.

${ }^{18}$ S. Sztobryn, Historia wychowania, Pedagogika, red. B. Śliwerski, t. 1 - Podstawy nauk o wychowaniu, Gdańsk 2006, pp. 1-77.
} 
the latest history of education as a form of comparison of the pedagogical ideas (S. Wołoszyn) and directing the whole spectrum of history of education towards the history of pedagogical ideas. So the postulate of keeping the historians of education gathered around the latest events (after 1945) was proposed in Rembertowo in 1993 by prof. K. Mrozowska and in Wrocław, in 2004, by prof. T. Hejnicka-Brzezińska. Moreover it is rather difficult to qualify the text by S. Sztobryn as a narrative from the history of philosophy or a draft of history of pedagogical ideas.

The lack of faith of some of the representatives of Polish pedagogy, in history of education resulted in the lack of clarity: either the history of pedagogical ideas or the history of pedagogy. The "pure" pedagogy accompanied by the idea of history with literature identity, which is easy to read, but for the pedagogy it does not bring anything constructive. ${ }^{19}$ When valuing this type there is a lack of classical approach of A. Toynbee from 1946, about the relationship between history, fiction and science. ${ }^{20}$ Taking into account the common memories of the past should not be associated with the history, scientific approach should be separated from the fiction one in the pedagogical reflection. Without the support of history of education it is rather impossible.

Atomization of the pedagogy which is displayed in a vast number of subdisciplines leads to separation from historicism and treating the history of education as anti-knowledge which should be omitted. ${ }^{21}$ It is taking place although the declarations that the latest history of education makes the present times more understood and allows pedagogy acquiring the understanding perspective, typical for the evolutionary changes. ${ }^{22}$ As a result the latest standards of university education in Poland at the pedagogy have limited classes of history

${ }^{19}$ P. H. Hutton, History as Art of Memory, Hannover-London 1993, p. 9; T. Stryjek, Przeszłość narodu i nurty dwudziestowiecznej historiografii, Kultura i Społeczeństwo 3-4/2001, p. 28 (after B. Szacka); R. Tomaszewki, Dobrowolnośc jako artybut historii wychowania, Treści historyczne w studiach pedagogicznych, op. cit, p. 110. ("In case of history we do not reasearch the past because it does not exist anymore" A. Ciążela.)

${ }^{20}$ A. Toynbee, Studium historii, Warszawa 2006, pp. 23-24.

${ }^{21}$ J. Dybiec, Historia wychowania w postmodernistycznym świecie, Biuletyn Historii Wychowania 1-2/2003, p. 9; S. Sztobryn, J. Semków, Kraków 2006, pp. 214-216; R. Tomaszewski, Historia wychowania jako synonim antywiedzy, Edukacja i jej historiografia..., op. cit., pp. 197-206.

${ }^{22}$ T. Hejnicka-Bezwińska, Konsekwencje a-historyczności pedagogiki, Pedagogika ogólna: tradycja-terażniejszość-nowe wyzwania, Bydgoszcz 1995, p. 77. Idem, Pedagogika Ogólna, Warszawa 2008, p. 172. At the same time prof. Hejnicka-Bezwińska makes a point in the fact that the latest history of education has a biographical factor in the of its creators, historians the direct witnesses or attendees of the vast events. 
of education. It resulted in the limited amount of subjects covered as well as the limited amount of classes in many subdisciplines. ${ }^{23}$

The reaction of the majority of academic pedagogical environment was the conference organised in October 2007. (The standards mentioned were a result of the laws passed by the Minister of Higher Education in July 2007.)

Co-organizers of the conference were The History of Education Society, The Institute of the History of Polish Academy of Science and the Pultusk University. The presence of the representatives of the above mentioned organizations proved the importance of educational disciplines in Poland.

To push away the accusation of the lack of objectiveness which might be the case when a historian of education writes about his discipline, the achievements of the conference resulted in words of professors. They are the published opinions of experts not dealing with history on everyday basis.

Prof. Bronisław Siemieniecki - "History of education makes an important element in creation of new theoretical conceptions in pedagogy";

Prof. Tadeusz Lewowicki - "...understood and explained are the doubts in historical creations. The predicted notions in their standards are too general";

Prof. Bogusław Śliwerski based his opinion on Paul Ricoeur: "...tradition is not a dead deposit, but a great source which should be creatively used. I would say even more - one of the duties towards the inheritance is to bring to life the elements of the past". ${ }^{24}$

The meeting in Pułtusk was concentrated on academic areas of education and history of education and the earlier attempts of their support in 2004-2007. At the same time another act of opposition was the initiative of Polish pedagogy in the twenties of the $20^{\text {th }}$ century. This argument over "pedagogism" or "non-pedagogism" of history of education was anagogic to the dilemma of locating the history of economy in economical studies and the laws in the law studies or other forms of use of historical knowledge. The dispute came into life directly after the $2^{\text {nd }}$ World War and was present during the $7^{\text {th }}$ Polish Historians Congregation in Wrocław, in $1948 .{ }^{25}$ Pedagogy at this point in time

${ }^{23}$ Rozporządzenie Ministra Nauki I Szkolnictwa Wyższego z dnia 12. 07. 2007 w sprawie standardów kształcenia. Zał 78.

${ }^{24} \mathrm{~K}$. Bartnicka (red.), Treści historyczne w nowej koncepcji studiów pedagogicznych, op. cit., pp. 44, 56 and 140. In case of prof. Śliwerski who based his ideas on P. Ricoeur's ideas it is worth to point out that they were developed and explained in the book Pamięć, historia, zapomnienie. Kraków 2006.

${ }^{25}$ A. Cwer, Czy historia wychowania jest dyscyplina naukowa - dyskusja w II Rzeczypospolitej, Treści historyczne..., op. cit., pp. 153-165. 
had not had a well established position. The relationship between history and pedagogy loosened. As the pedagogy expanded history of education was accused of not having their own paradigm, but this gap had been filled with "a specific character of contemporary postmodern historiography". As a criterion of its usefulness educationalists introduced the term "pedagogical history of education" and suggested the reduction of historical and pedagogical ideas. ${ }^{26}$

Polish critics of history of education missed on a paradigm existing since the 20 s of the $20^{\text {th }}$ century, created by the Annalysts in which "... history should become what should always be: the research of the contemporary". ${ }^{27}$ Fernand Braudel was promoting the arrangement of "A Common Council on the Basis of the Studies on Human". For Polish educationalists such paradigm functioning over 800 years became a discovery of the $21^{\text {st }}$ century. The reduction of historicism in the studies of education would have to result in the filling the gap by the "directed mythology" about which prof. Świderski has warned us. ${ }^{28}$ However, the reduction of history of education to the history of pedagogical ideas would lead to the description of history of imaginary events. The pedagogical reflection, no matter its paradigm, should be historically organized because there is no thought or idea from nowhere! ${ }^{29}$ History is a record of the development not the imagination of the development. It can be treated as literature without the burden of education and object to its development. So where should we take our courage from to educate?

The alternative for the absence of the history of education are the ideas of the suitable to the past fitting into the future directed by the educationalists. They are, however, in this case, only the colourful extras, not the support or the order. For this reason the presence of the educationalists after the sixth year

${ }^{26}$ C. Majorek, Najnowsza historia edukacji wobec potrzeb pedagogiki, Educational ways, ed. S. Kowal and R. Kwiecińska, Kraków 2002, p. 46; S. Sztobryn, Polskie badania nad myśla pedagogiczna w latach 1900-1939 w świetle czasopiśmiennictwa. Ujęcie metahistoryczne, Łódź 2000, p. 6; Idem, Historia wychowania, Pedagogika, red. B. Śliwerski, t. 1 - Podstawy nauk o wychowaniu, Gdańsk 2006, p. 4.

${ }^{27}$ F. Braudel, op. cit., p. 444.

${ }^{28}$ B. Śliwerski, Ewolucja modeli oraz autonomii i uspotecznienia szkoty w okresie III Rzeczypospolitej, Szkoła - Państwo - Społeczeństwo między autonomią a podległością, Gdańsk 2009, pp. 23-24; M. Turlejska, Zapis pierwszej dekady 1945-1954, Warszawa 1972, p. 7.

${ }_{29} \mathrm{~J}$. Topolski, $O$ mitach $w$ badaniu przeszłości, Metodologiczne problemy badań nad dziejami myśli historycznej, ed. J. Maternicki, Warszawa 1990, pp. 52-53; P. Zwierzchowski, Myślenie mityczne w pedagogice ( $w$ świetle koncepcji mitu Ernesta Cassiera), Bydgoszcz 1997, pp. 28, 42 and 64 (the author is wrong - the mythical thinking does not finish with Socialist Pedagogy - p. 57). 
absence in the work of the $17^{\text {th }}$ Polish Historians Congregation, which took place in September 2009 in Olsztyn. ${ }^{30}$ The presence of the history of education specialists alongside with the historians of other specialism for the first time since 1948 was noticed and approved. It much harder to gain such approval of a part of representatives of educational disciplines especially when historians of education are absent during the pedagogical congregations - although the history of education tried to create their own section. The pedagogical accusations which state that Polish history of education is antiquarian and eventful are not right as in this case it is simply becoming boring. There is a tendency of pushing aside the history in pedagogy. However there is an improvement of quality of the historical researches and the display of priorities for the latest events; also within history of thoughts and systems of education and the evolution of educational systems. "History of education gives pedagogy and the educationalists a chance to function in the "World with history". This statement by the historian prof. K. Jakubiak supports the opinion of Jose Ortega y Gasset "a human does not have a nature but a history". 32

There are two basic areas of gathering the knowledge. The first one is history which is the reason for the disputes within the educational arguments leading to its reduction but made to think even more. The second one is internet, so the virtual word which does not enhance thinking. Perhaps the "human gap" described in the report of the Roman Club is the reason for not taking into account history. The question about the condition of the history of education which was the key issue during the conference in Olomouc in November 2009 is still a valid aspect. It is proved by the discussion over Polish historicism in pedagogy lasting from 1918 up to now (2010). Historicism makes difficult the assessment of the past reforms in education. The lack of historicism in educational disciplines will lead to pedagogy being taken over by politics.

\footnotetext{
${ }^{30}$ The main role in organising the section of the Historians of Education had prof. W. Szulakiewicz from the University of Mikołaj Kopernik in Torun. She also described the attendance of pedagogical staff in other congregations of historians. S. Szulakiewicz, Z dziejów uczestnictwa historyków wychowania w zjazdach historycznych, Z dziejów polskiej teorii i praktyki edukacyjnej, Toruń 2009).

${ }^{31}$ F. Braudel, op. cit. pp. 10-19.; T. Hejnicka - Bezwińska, Pedagogika ogólna, Warszawa 2008, p. 437.

${ }^{32}$ J. O. y Gasset, Bunt mas, Warszawa 2002, pp. 95-96; K. Jakubiak, Tradycje i aktualność $w$ dyskusji o roli użyteczności historii wychowania w ksztatceniu pedagogicznym, Treści historyczne..., op. cit. pp. 38.
} 


\section{Bibliography}

APPELBY, J., HUNT, L., JACOB, M. Powiedzieć prawdę o historii, Poznań 2000.

BARTNICKA, K. (red.), Treści historyczne w studiach pedagogicznych, Pułtusk 2007.

BRAUDEL, F. Gramatyka cywilizacji, Warszawa 2006.

BREZINKA, W. Wychowania i pedagogika $w$ dobie przemian kulturowych, Kraków 2008.

DYBIEC, J. Historia Wychowania w postmodernistycznym świecie, Biuletyn Historii Wychowania 1-2/2003.

FUKUYAMA, F. Koniec historii, Poznań 1996.

Y GASSET, J. O. Bunt mas, Warszawa 2002.

HEJNICKA-BEZWIŃSKA, T. Pedagogika ogólna, Warszawa 2008.

HEJNICKA-BEZWIŃSKA, T. Pedagogika ogólna: tradycja - teraźniejszość nowe wyzwania, Bydgoszcz 1995.

HEJNICKA-BEZWIŃSKA, T. Racjonalność pedagogiki, Bydgoszcz 1995.

HUTTON, P. H. History as Art. Of Memory, Hannover - London 1993.

KOWAL, S., KWIECIŃSKA, R. (red.).

KWIECIŃSKI, Z., ŚLIWERSKI, B. Pedagogika. Podręcznik akademicki, t. 1, Warszawa 2003.

MATERNICKI, J. Metodologiczne problemy badań nad dziejami myśli historycznej, Warszawa 1990.

NIPPERDEY, T. Rozważania o niemieckiej historii, Warszawa 1999.

RICOEUR, P. Pamięć, historia, zapomnienie.

SEMKÓW, J., SZTOBRYN, S. Historia i jej historiografia. W poszukiwaniu ptaszczyzn twórczego dialogu, Kraków 2006.

Standardy.

STRYJEK, T. Przesztość narodu i nurty dwudziestowiecznej historiografii, Kultura i Społeczeństwo 3-4/2008.

SZACKA, B. Czas przeszły pamięć mit, Warszawa 2006.

SZTOBRYN, S. Polskie badania nad myśla pedagogiczna w latach 1900-1939 w świetle czasopiśmiennictwa. Ujęcie metahistoryczne, Łódź 2000.

SZULAKIEWICZ, S. Z dziejów uczestnictwa historyków wychowania w zjazdach historycznych, Z dziejów polskiej teorii i praktyki edukacyjnej, Toruń 2009.

ŚLIWERSKI, B. Ewolucja modeli oraz autonomii i uspotecznienia szkoły w okresie III Rzeczypospolitej, Szkoła - Państwo - Społeczeństwo między autonomia a podległością, Gdańsk 2009. 
ŚLIWERSKI, B. Pedagogika, t. 1 - Podstawy nauk o wychowaniu, Gdańsk 2006. TOFFLER, A. Szok przyszłości, Poznań 1998.

TOYNBEE, A. Studium historii, Warszawa 2006.

TURLEJSKA, M. Zapis pierwszej dekady 1945-1954, Warszawa 1972.

ZWIERZCHOWSKI, P. Myślenie mityczne w pedagogice, Bydgoszcz 1997.

\section{Contact address:}

Roman Tomaszewski,

Akademia Pomorska w Słupsku,

Zakład Historii Oświaty i Wychowania, Instytut Pedagogiki,

76 - 200 Słupsk, ul. Arciszewskiego 22,

Polska 